\title{
Remittance Trap: Comparative Approach of the Republic of Moldova and Other Ex-Socialist Countries
}

\section{Elina BENEA-POPUȘOI ${ }^{*}$, Polina ARIVONICI ${ }^{2 * *}$}

\begin{abstract}
The objective of our analysis has been to find out and elaborate on why some countries could not benefit from remittance inflows sent by migrants or even are getting into traps due to them. In the authors' view, the remittance trap may be appraised, notably in the long run, as the dilemma in which a country finds itself when the high value of migrant remittance inflows leads to a high value of human and financial capital outflows, as well as to the moral hazard problem of the country's population and government. Accordingly, remittance trap negatively affects the sustainable growth and development of the economy which eventually deepens the country's dependence on remittances, proving the vicious nature of the trap. Furthermore, the paper focuses on identifying a competent set of policy recommendations for the countries that are remittance dependent. A natural conclusion of our research is that there is a thin line between remittances' advantages and disadvantages, since in fact, short-term benefits very often turn out into long-run side effects, mainly as a result of mismanagement of remittance inflows, which correlates with unfavourable business climate and decreased willingness of the population to invest. Accordingly, the benefits and adverse side effects of remittance inflows are interdependent.
\end{abstract}

Keywords: migration, remittances, side effects of remittances, moral hazard problem, Dutch Disease phenomenon, ex-socialist countries, remittance trap.

JEL Code: F22, F24, F63, F66

\footnotetext{
$1^{*}$ Elina Benea-Popuşoi, Dr., Associate Professor at the Academy of Economic Studies of Moldova, International Business Department. https://orcid.org/0000-0001-9102-9682 Emails:<elinabenea@gmail.com>; <elina.benea-popusoi@ase.md>

${ }^{2 * *}$ Polina Arivonici, Academy of Economic Studies of Moldova. Email: <77polina.m7@mail.ru>
} 


\section{Introduction}

Remittances continue to be one of the major financial sources for families and play a crucial role in co-insurance or risk mitigation in times of hardship in the worldwide economy (Ratha, 2013, p.9). Remittances can amplify the welfare of family members left behind and boost the economies of receiving countries (Amuedo-Dorantes, 2014, p.1). Taking into consideration that the volume of remittances is continuously increasing, it is supposed that these inflows could potentially fuel the socio-economic progress in the Republic of Moldova, as well as in the other ex-socialist countries. Furthermore, if these inflows will sustain the investment in human capital and technology and thereby, boost labour productivity, these would then help to balance economic aftereffects caused by population aging and brain drain.

Nevertheless, scholars continuously argue about the side effects of remittances on sustainability of economic development. Thus, remittances may create a culture of dependency and decelerate economic growth in the recipient country. Hence, a better understanding of their consequences is needed to empower developing economies to get the greatest benefit from these monetary inflows (Amuedo-Dorantes, 2014, p.2). Moreover, we have sought to formulate relevant policy recommendations, with a view to create an encouraging business and legal environment, boost the population's marginal propensity to invest, and get out of the remittance trap.

For the purpose of elucidating the various implications of remittances, apart from the introduction, literature background, methodology framework, and conclusions, we have organized the main findings of our research into 5 sections, examining the current trends in migrant remittances, the effects of remittances on key macroeconomic issues, elaborating about the investment climate in remittance recipient countries, the link between remittances and moral hazard problem, the Dutch disease phenomenon. In the next part of the article, based on our conception regarding remittance trap as the dilemma in which a country finds itself when the high value of migrant remittance inflows leads to a high value of human and financial capital outflows, as well as to the moral hazard problem of the country's population and government, we set out to formulate policy recommendations that would support countries to avoid such vicious trap of remittances. 


\section{Literature review}

In the case of ex-socialist countries, the phenomenon of remittances and migration has been tackled in various studies, primarily from the perspective of their influence on social and economic progress, becoming the focus of a number of discussions and analyses made by scholars, public authorities, and by the whole civil society. For instance, Amuedo-Dorantes (2014), the author of The good and the bad in remittance flows, points out that at a macroeconomic level, remittances have been found to harm the export sector and exchange rates through the so-called Dutch disease phenomenon. Dutch disease relates to the negative effects of large increases in a country's income, whether from foreign direct investments, natural resources, foreign aid, or remittances, as in our case. "The increases lead to a decline in the competitiveness of a country's manufactured exports and an increase in imports" (Amuedo-Dorantes, 2014, p. 2). Likewise, Valetka (2013) claims that in a manner, remittances and labour migration create a moral hazard for the government, as remittances take the pressure off the governments. Thus, the moral hazard problem is tackled in the IMF Working Paper Remittances and Institutions: Are Remittances a Curse? (Abdih, Chami, Dagher \& Montiel, 2008). The authors consider that remittances act as a buffer between the government and its citizens since these financial inflows allow households not to rely on public goods and services provided by the government, which reduces the household's incentive to hold the government accountable and, in that way, deepens the remittance trap. The government can then free ride and divert resources from the efficient delivery of public goods and services (Abdih et al., 2008).

Concurrently, Di John (2011) has contested the validity of resource curse and the Dutch disease phenomenon and asserted that the extent to which the natural resource windfall generates developmental outcomes depends largely on many factors.

On the other side, Stratan \& Chistruga (2012) in their paper "Economic consequences of remittances. The case of Moldova" assert that remittances have played a notable role in boosting economic growth, through their effect on consumption. Nevertheless, GDP growth is fuelled mainly by the rise in consumption, which is not a tenable growth. Olga Kupets (2012) claims that an efficient financial system can channel the saved remittances towards the 
most fruitful projects, in that way tackling the development potential of remittances, while preventing their counterproductive side effects.

\section{Methodology framework}

The authors have explored both theoretical sources and empirical evidence in their attempt to clarify the manner and circumstances in which migrants' remittances succeed or fail to contribute to sustainable economic development. Based on the latter cases, we conceptualized the notion of remittance trap as the dilemma in which a country finds itself when the high value of migrants' remittance inflows leads to a high value of human and financial capital outflows, as well as to the moral hazard problem of the country's population and government. In this regard, we capitalized on theoretical-structural approaches such as the analysis-synthesis, and on the theoretical-logical approaches including the inference method, the method of analogy, logical deduction.

Furthermore, we have relied on the systemic approach, in our endeavour to reveal the causal relationship between the remittance inflows and some core macroeconomic issues in the recipient country, such as inflation, unemployment, poverty reduction, human capital development, and investment climate. We mainly focused on examining and evaluating the 2 defining problems of the remittance trap - the moral hazard problem and the Dutch disease phenomenon. With a view to argue the issue of remittance trap, we conducted a comparative case study on selected countries, providing statistical illustrations.

Specifically, for the comparative case study on the selected ex-socialist countries - R. Moldova, Lithuania, Latvia, Armenia, Georgia, Tajikistan, Kyrgyz Republic, we have conducted both qualitative and quantitative research, including longitudinal analysis.

The countries were selected based on a number of similarities with the Republic of Moldova. For instance, all the countries are ex-Soviet countries from Europe and Central Asia with a relatively high share of remittances in GDP, between $11 \%$ and $29 \%$, compared to the regional average of $1.92 \%$ in 2019 excluding high-income economies (World Bank, 2019).

However, at the national level of ex-Soviet countries, in particular, those included in our comparative case study, we have ascertained some difficulties in estimating migrants' remittances, because of poor data quality on this issue. 
At times, it was also difficult to distinguish between the impact of remittances and that of other sources of income on the inequality in the region.

Likewise, scholars acknowledge the challenge of measuring the longterm impact of remittances on human capital development. Consequently, we analysed the effects of remittances on human capital formation in the region using indirect evidence and secondary information.

Considering the above, we have primarily relied on data provided by specialized intergovernmental organizations mainly the World Bank, the International Monetary Fund, and by international non-governmental organizations such as The Heritage Foundation, delivering various indexes, notably the Index of Economic Freedom.

\section{Main findings}

\subsection{The current trends in migrant remittances}

To analyse the current trends in migrant remittances, we must take into consideration the economic crisis caused by the COVID-19 pandemic which negatively influenced employment for migrant workers and their wages. Even though globally remittances flows remained steady in y. 2020, recording a smaller drop than previously forecasted, and the recorded drop in remittance flows $(1.6 \%)$ in 2020 was smaller than the one during the 2009 global financial crisis $(4.8 \%)$, remittances to Europe and Central Asia lowered by about $9.7 \%$ to $\$ 56$ billion in 2020 as the global pandemic and feeble oil prices had a significant impact on migrant workers across the region. Furthermore, the depreciation of the Russian rouble seriously diminished the US dollar value of remittance flows to the region (World Bank, 2021).

The dynamics of migrant remittances inflows in some countries from the region is presented in Figure 1.

As we can see from the graph, after a substantial decline in the year 2014, beginning with 2016 countries started to register an overall increase in remittance inflows, except the Kyrgyz Republic where remittances tend to significantly decrease beginning with y. 2018. However, in 2020 these declined, because of the economic crisis caused by the COVID-19 pandemic and weak oil prices. Moreover, "for 2021, remittance flows are estimated to fall further by $3.2 \%$ as the region's economies are expected to recover from the crisis slowly" (World Bank, 2021). 
In the case of Latvia and Lithuania, ex-socialist countries that are already integrated into the EU, although their economies are also relatively small, however, the value of GDP is higher and the amount of remittances is considerably lower, which fact does not indicate a substantial dependence on remittance inflows.

Figure 1. Migrant remittances inflows, years 2010-2020

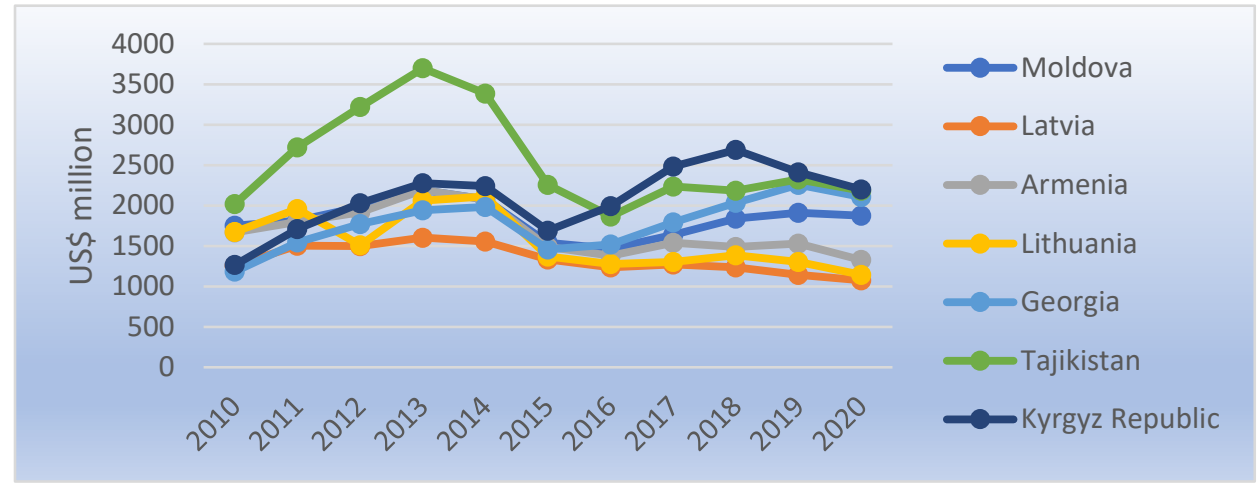

Source: Elaborated by authors, based on The World Bank's Migration and Remittances Data (2021)

\subsection{Effects of remittances on key macroeconomic variables \\ 3.2.1. The effect of remittances on inflation}

The impact of remittances on inflation can be viewed from different standpoints. According to Stratan, Chistruga, Clipa, Fala and Septelici (2013):

... the resulting effect of a large inflow of remittances will be the appreciation of the exchange rate and a rising price level. The inflow of remittances determines an increase in the household income, which leads to a rise in aggregate demand. The higher demand can imply a rise of inflation. (p. 35)

Apparently, the conversion of the foreign exchange into national currency raises the money supply, thus generating inflation. An increase in the household disposable income may be followed by a decrease in the labour supply. This in turn would result in an increase in the general price level, due to higher costs of production. 
Concurrently, some authors argue that under a flexible fiat standard it is debatable that an inflow of foreign currency can raise the prices expressed in the national currency (Di John, 2011).

In order to analyse the presence of mutual causality, a VAR model is typically used. The VAR model showcases a remarkably small impact of remittances on inflation which is presumably due to the huge share of the trade deficit in GDP that determines depreciation of the domestic currency and offsets appreciation pressure from remittance inflows, a common symptom for the countries being in the remittance trap (Stratan et al., 2013). It is quite complicated to quantify the volume of remittances that is spent for domestic products and for foreign ones, but clearly the scarce national production capacities are causing the imports to increase in the same proportion as remittances. The national currency has little appreciation and the inflation rate has an adequate trend consequently (Benea-Popuşoi \& Arivonici, 2021).

\subsubsection{The effect of remittances on unemployment}

The subtraction of the labour force is the most evident effect of migration on the economy of a donor country. Furthermore, in the view of Stratan et al. (2013):

Remittances from migrants to their family raise the income of the unemployed individuals from home. This will reduce the difference between the incomes of those employed and unemployed in the home country, thus limiting employing intentions and causing the unemployment rate to rise. (p. 33).

At the same time, evidence shows that migration can also reduce unemployment when a large number of workers leaves the country, resulting in higher wages for those staying behind. These effects at the individual/household level can have an impact at the aggregate level. Aggregate demand may be enhanced by high levels of remittance flows into labour markets and accordingly the demand for labour. As a result, remittances, indirectly, reduce unemployment by having a persistent impact on investment. So, as in the case of inflation, we can observe an offsetting. 


\subsubsection{The effect of remittances on poverty reduction}

As a general rule, remittances directly contribute to poverty relief, providing financial resources for education, medical service and everyday consumption. A poor-income family receives not only a source of financial help, but also a type of social insurance, having a migrant abroad, which can protect them during an economic crisis in their country. Nevertheless, remittance inflows have contradictory effects on income inequality in the exSoviet countries. On the one hand, these give a chance to the poor to improve their financial situation by working in a more developed country. On the other hand, families that are not able to send their members abroad find themselves in a negative economic situation. An example of the negative impact of remittances on income inequality is Republic Moldova, where mainly families with a better economic situation may send their members to the European Union, while migrants from poor-income families can only afford to work in former soviet space, above all in Russia (Benea-Popușoi \& Arivonici, 2021).

\subsubsection{The effect of remittances on human capital development}

It is challenging to measure empirically the impact of remittances on human capital development in the long term. Considering this, we have examined the formation of human capital in the region, primarily using secondary information and indirect evidence.

In the Republic of Moldova, the impact of remittances on human capital development is debatable. According to researches, including those of Stratan et al. (2013):

... remittances contribute to reducing liquidity constraints of receiving households to finance their children's education and thus influencing positively the development of human capital, the evidence shows that especially in rural area, households receiving remittances are more likely to invest in education ... (p. 10).

At the same time, the benefits of remittances on human capital are counterbalanced by the negative effects of the massive emigration of qualified specialists and of the brain drain. Furthermore, migration has a crucial impact 
on the psychological and emotional state of children, that also affects their academic performance (Benea-Popușoi \& Arivonici, 2021).

\subsection{Investment climate in the remittance recipient countries}

For the Moldovan economy, the external migration phenomenon became an indispensable pattern in the last decades. The movement of Moldovan citizens has been spurred across the world due to society's aspirations for a better future and its motivation to seek higher earnings, as well as other incentives (Stratan et al., 2012). Furthermore, the Republic of Moldova is one of the countries that relies the most on remittances, in y. 2019 being one of the top 3 remittance receivers in Europe and Central Asia (as a percentage of GDP), among other two ex-Soviet countries: R. Moldova (16\%), Tajikistan (28.6\%), Kyrgyz Republic (28.5\%) (World Bank, 2019).

The distributional impact of revenues from abroad is not much tackled, because of the arduous character of data collection on this issue. However, the available statistics and surveys suggest that remittances mainly fuel consumption which thus becomes the main driver of the GDP growth (Stratan et al., 2012). They have only a limited impact in terms of poverty reduction and are invested to a limited extent. In most cases, unfavourable investment climate, poor public governance, and weak institutions explain this phenomenon in developing countries. As well, one of our major findings is that these factors are the main reason why a country receiving remittances cannot escape the remittance trap and properly benefit from these financial inflows (Benea-Popuşoi \& Arivonici, 2021).

Three indexes that describe the investment climate in the Republic of Moldova in comparison to some other countries in the region are presented further. We examined the same countries as in the first part of the paper, when analysing migrant remittances inflows. 


\section{Figure 2. Regulatory Quality Index, 2010-2019}

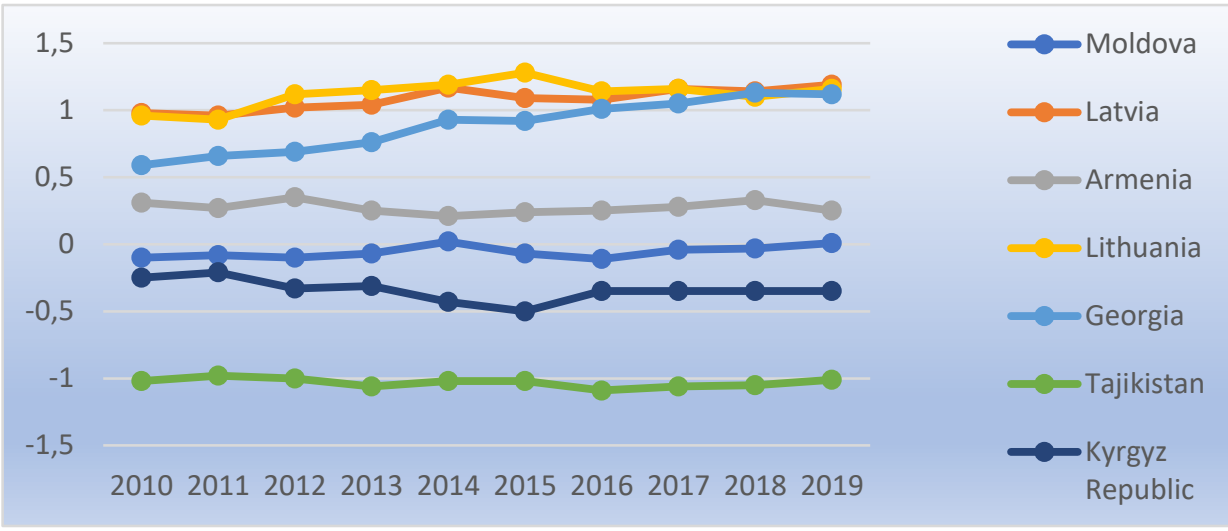

Source: Elaborated by authors, based on The World Bank's Worldwide Governance Indicators data set (2021)

The regulatory quality index and government effectiveness index, estimated by the World Bank in a number of countries, are described in the Figure 2 and Figure 3. Analysing them, we can mention that R. Moldova progressed modestly compared to other countries in the region for the quality of governance over the recent decade, remaining relatively low, but outpacing Tajikistan and the Kyrgyz Republic. The largest, and growing discrepancy being against Georgia, Lithuania, and Latvia.

\section{Figure 3. Government effectiveness index, 2010-2019}

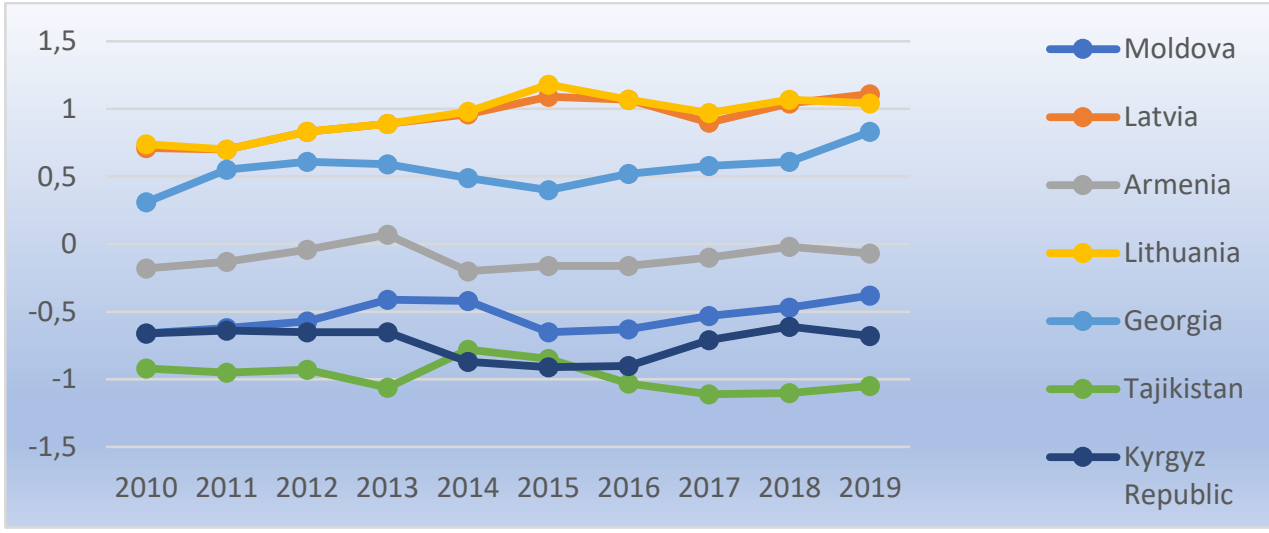

Source: Elaborated by authors, based on the World Bank's Worldwide Governance Indicators data set (2021) 
In particular, in the case of Latvia and Lithuania, although socialist countries in the past, the EU integration process has considerably improved the quality of their institutional environment, implicitly their investment climate, consequently entailing less emigration of citizens and much less reliance on migrant remittances. By contrast, in our country, as stated in the National Strategy for Investment Attraction and Export Promotion 2016-2020 (2016):

... whereas the regulatory reforms marginally improved the life of existing investors, it did not make Moldova much more attractive for potential investors. In addition, the recent bank fraud brought out the issue of moral hazard that negatively impacts business climate in the country [in 2014, \$1 billion disappeared from three Moldovan banks Banca de Economii, Unibank and Banca Socială - it is thought to have been a coordinated effort to extract as much loan finance as possible from the banks without any obvious business rationale]. (p. 45-46)

Figure 4. Property rights and freedom from corruption indexes, 2016
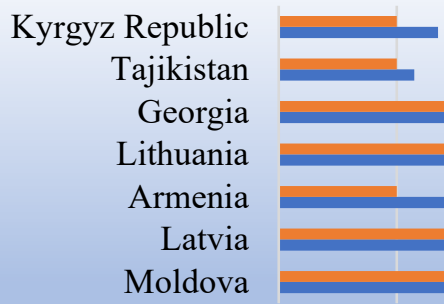

$$
\text { a }
$$
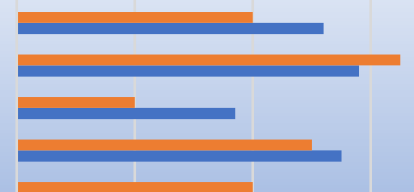

$\begin{array}{llll}0 & 20 & 40 & 6\end{array}$

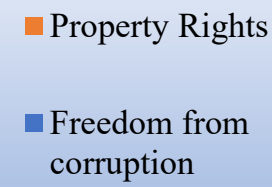
corruption

\section{Freedom from} (corruption 
property rights. Moldova earned one of the lowest scores in the region according to the rule of law components of the index: freedom of corruption and property rights. (p. 47)

Some people consider corruption a kind of a tax. From this point of view, gaining a profit is quite hard in the Republic of Moldova and normally, this fact is repulsive for the investors. Although in the case of countries with high transaction costs, including Republic of Moldova, in terms of continuity of production activities, corruption can sometimes help debottleneck these activities, allowing one to continue production even though $\mathrm{s} / \mathrm{he}$ does not comply with all the bureaucratic requirements.

While analysing the long-run impact of remittances, we consider as very relevant the factors that determine the quality of the institutional environment and the level of transaction costs, as they ultimately influence the population's marginal propensity to invest in the domestic economy, this in turn affecting the long-run economic development of the country receiving remittances.

\subsection{Remittances and moral hazard problem}

In our view, remittances entail the moral hazard problem in two ways.

First, once family members who remained home can benefit from financial sources sent by the migrant, they are substantially less motivated to increase their labour force participation, while the temptation to have more leisure time becomes bigger.

Second, large financial inflows allow the governments to be less responsive to the people's needs and complaints. Clearly, families receiving remittances are better ensured in the cases of economic instabilities and shocks. Moreover, being in a favourable economic situation, families may have a romantically distorted overview of the country, as a result, they are less likely to monitor government efficiency and the fulfilment of election promises. In this case, politicians are less likely to fulfil their obligations to the people. Remittances ease the life of politicians by the fact that they improve the lives of many recipient families. As a result, these families are less likely to complain about their living conditions or quality of government than if these families did not have access to financial flows from abroad. This fact fuels the real encouragement of migration and remittances, hence the 
remittance trap becomes more and more difficult to escape (Chami, Ernst, Fullenkamp \& Oeking, 2018).

For instance, using a large sample of developing countries, Abdih et al. (2008) have shown that large remittance inflows reduce the quality of institutions in the recipient country. This occurs because the access to remittance money makes government corruption less costly for domestic households to bear, consequently, corruption is likely to increase. Moreover, Barajas et al. (2009) show that if conditions are bad at home, families tend to send more members to work abroad and use remittances to compensate for the lack of government services. Hence, the incentive in pressuring the government to offer services of better-quality declines. Households can fend for themselves, the government understands this and does not feel induced to provide services, as a result, government efficiency declines.

On the other hand, we should not ignore the pressure that the diaspora can put on the home country's politicians. Thus, diaspora's access to funds, ideas, and undistorted information could represent a major catalyst for change.

Referring to the case of the Republic of Moldova, we would like to mention one of the interviews with the current President of our country, Ms Maia Sandu, dedicated to Moldova's 30th independence anniversary. Thus, in her interview for Radio Europa Liberă Moldova by V. Botnaru, the President states that massive migration has been a very detrimental factor for our society, since it has taken away a big part of our young population which could have put pressure on the government, thereby intimidating authoritarian corrupt regimes. In the absence of such pressure, unscrupulous politicians have found it quite easy to face the resistance of the old generations, by empty promises, "electoral charity" and by translating through the captured media channels the "right" news and information (Radio Europa Liberă Moldova, 2021).

\subsection{Remittances and Dutch Disease Phenomenon}

Like any other foreign currency inflows, massive remittance inflows can cause an appreciation of the real exchange rate and increase the price of traditional exports. Even though empirical evidence of such "Dutch disease" effects of remittances is limited, the impact is likely to be large in small economies. For instance, some countries, including El Salvador, Kenya, and 
R. Moldova, are worried about the effects of large remittance inflows on currency appreciation. Moreover, the symptoms of the "Dutch disease" phenomenon in Moldova were attested for the period of 2004-2012, when the average increase by $10 \%$ of remittances was causing a really effective appreciation of the national currency of $0.9 \%$ (Prohniţchi et al., 2013). At the same time, the link is opposite for the period 1997 - 2003, when the inflows of remittances were more modest. Thus, they tend to have an adverse effect on the exporters' competitiveness primarily during the more robust economic growth periods (Prohnițchi et al., 2013).

The growing consumption of recipient citizens may increase the local market price and appreciate the exchange rate. As a result, the failing of the tradable sector of the domestic economy, the rising current account deficit, and inflation with weaker monetary control may occur (Kireyev, 2006). Meanwhile, the growing pressure on wages may lead to job losses in the tradable sector, while the sudden rise of prices would increase the labour costs in the non-tradable sector, thus leading to the loss of national competitiveness (Lubambu, 2014).

Taking into account the symptoms of the "Dutch disease" phenomenon, governments have to acknowledge the problems deriving from the consumption of remittance recipient persons and accordingly, set up business incentives that would stimulate long-term investments, which in turn could generate benefits for the whole society.

\section{Policy recommendations}

As stated above, business climate and the population's marginal propensity to invest at home are important factors to consider while attempting to maximize the advantages linked to Moldovan external migration. As a result, governmental intervention is crucial and should strive for goals including maintaining emigrants' interest in the country's evolution and the development process, improving the information about business prospects, spending of the remittances in the official economy, increasing the access to formal money transfers from abroad.

Following our analysis, we have synthesized some policy recommendations for the Republic of Moldova, which may also be applicable for other ex-socialist countries. 
Thus, in order to boost the investment of migrant remittances into the economy of their origin country, it is essential to keep reduced transaction costs. As some authors pointed out (Valetka, 2013) growing financial literacy, and widening the set of financial instruments for households on the policy agenda matter too. As suggested in the "National Strategy for Investment Attraction and Export Promotion 2016-2020" (2016), the government might create a specialized organization to channel remittances for investment purposes, by offering inter alia, less expensive credits or higher awards for business purposes. To apply for these advantages, migrants or their families would need to demonstrate the provenance of their money. In particular, R. Moldova has implemented "PARE 1+1" program, deemed to be a decent beginning for engaging the diaspora's financial potential in the economic development of the country.

However, the limited effects of programs such as "PARE 1+1" have been largely criticized. For example, some beneficiaries of "PARE 1+1" claim that they no longer want to resort to the state, because of bureaucracy, and that any support from the state is hardly given, they have to allocate too much time for traveling and documents, whilst the time for them is more important. Moreover, they declare that a little is offered to them, whereas the requirements are too high and that this money is spent mostly on custom fees when bringing equipment from abroad. They believe that once they have received this support from the state it would have been good to be exempted from VAT, but that way, they imported equipment in the country and gave the money back to the state, for VAT (Razmerița, 2014).

Therefore, while considering the limits of the state in the management of remittances, neoliberal recipes suggest that lower taxes to encourage production, savings, investments and the elimination of regulations that would allow a flexible and quick reallocation of resources from uncompetitive sectors, remain the best solutions for channelling resources from remittances into wealth enhancing activities.

By the same token, there is a need to build the capacity of institutions and human resources to lead research into the whole spectrum of remittances and labour migration matters in accordance with international standards (National Strategy for Investment Attraction and Export Promotion 20162020, 2016). Household and individual surveys on migration issues may 
complement official sources based on the balance of payments, by providing important information on the origins, destinations, and amounts of remittances received by households.

Likewise, it is important to reduce legal obstacles to labour mobility between R. Moldova and the EU countries. The efforts should be coordinated towards effective migration management, including such important subjects as illegal migration, cross-border human trafficking, the mutual recognition of professional qualifications, skills matching between migrant workers and jobs abroad, and the portability of pensions, health, and other social benefits (Kupets, 2012).

\section{Conclusions}

Remittances play a significant role in the economic development of the Republic of Moldova and other countries in the region and in general have a positive impact on the economic development of the ex-socialist countries. Nevertheless, they determine negative effects as well.

Primarily, the loss of labour resources is a serious problem slowing down the development of the Republic of Moldova's economy. Moreover, a large share of remittances in the national economy results in macroeconomic problems, such as Dutch disease and consumption-based growth.

Hence, countries have to acknowledge the risk of falling into the remittance trap, which may be viewed, notably in the long run, as the dilemma in which a country finds itself when the high value of migrant remittance inflows leads to a high value of human and financial capital outflows, as well as to the moral hazard problem of the country's population and government. Accordingly, remittance trap negatively affects the sustainable growth and development of the economy which eventually deepens the country's dependence on remittances, proving the vicious nature of the trap.

The main remedy for escaping remittance trap, for mitigating Dutch disease, is improving the competitiveness of industries that deal with foreign competition. This remedy includes boosting a country's physical infrastructure, upgrading the education system, and lowering the cost of doing business. Also instead of contemplating migration, governments may play more active role in promoting the formation of new businesses, by seed funding and other financial assistance for start-ups. 
Moreover, empirical studies suggest that a growing number of labour migrants and remittance amounts from them reduce the pressure to implement economic reforms in their home countries, leading to the moral hazard problem of both the population and government, which in turn seriously challenges the long-term development of the ex-Soviet countries. In this context, it is worth mentioning the importance of adequate state policy interventions which could direct the remitted financial inflows towards productive investments instead of conspicuous consumption.

\section{References}

Abdih, Y., Chami, R., Dagher, J., \& Montiel, P., (2008). Remittances and Institutions: Are Remittances a Curse? IMF Working Papers, 08(29). https://doi.org/10.5089/9781451868913.001

Amuedo-Dorantes, C. (2014). The good and the bad in remittance flows. IZA World of Labor. https://doi.org/10.15185/izawol.97

Barajas, A., Chami, R., Fullenkamp, C., Gapen, M. T., \& Montiel, P. (2009). Do Workers' Remittances Promote Economic Growth? IMF Working Papers, 09(153). https://doi.org/10.5089/9781451873009.001

Benea-Popușoi, E. \& Arivonici, P. (2021). Remittances and their side effects on economy: comparative approach of the Republic of Moldova and other ex-socialist countries. CSEI Working Paper Series, 17, 26-33. https://csei.ase.md/wp/files/issue17/WP_Issue17_26-33_BEN.pdf

Chami, R., Ekkehard, E., Fullenkamp, C., \& Oeking, A. (2018, September). Is There a Remittance Trap? IMF Finance \& Development Magazine, 55. https://www.imf.org/external/pubs/ft/fandd/2018/09/is-there-aremittance-trap-chami.htm

Di John, J. (2011). Is There Really a Resource Curse? A Critical Survey of Theory and Evidence. Global Governance: A Review of Multilateralism and International Organizations, 17(2), 167-184. https://doi.org/ 10.1163/19426720-01702005

Kireyev, A. (2006). The Macroeconomics of Remittances: The Case of Tajikistan. IMF Working Papers. https://doi.org/10.5089/ 9781451862621.001

Kupets, O. (2012). The Development and the Side Effects of Remittances in the CIS Countries: The case of Ukraine. CARIM-East Research Report. https://cadmus.eui.eu/handle/1814/23477

Lubambu, K. M. K. (2014). European Parliament, Directorate-General for External Policies of the Union. The Impacts of Remittances on 
Developing Countries. Publications Office. https://doi.org/ $10.2861 / 57140$

National Strategy for Investment Attraction and Export Promotion of Republic of Moldova 2016-2020 (2016). https://mei.gov.md/sites/ default/files/snaipe_2016-2020_eng.pdf

Prohniţchi, V., \& Lupuşor, A. (2016). Options for harnessing emigrants' remittances and savings for the development of the Republic of Moldova UNDP in Moldova. UNDP. https://www.md.undp.org/content /moldova/en/home/library/inclusive_growth/emigrants_remitances.html

Radio Europa Liberă Moldova (2021). Maia Sandu: Reälizarea majoră a celor 30 de ani e că nu am permis niciunui regim autoritar să prindă rădăcini [interview by V. Botnaru, on August 23, 2021]. https://moldova.europalibera.org/a/maia-sandu-realizareamajor\%C4\%83-30-de-ani-este-nu-am-permis-regim-autoritars\%C4\%83-prind\%C4\%83-r\%C4\%83d\%C4\%83cini/31423924.html

Ratha, D. (2013). The Impact of Remittances on Economic Growth and Poverty Reduction. Migration Policy Institute. https://www.migrationpolicy.org/pubs/RemittancesPovertyReduction.pdf Razmeriță, R. (2014). "PARE $1+1$ " or adding by subtraction. Ziarul de Gardă.https://www.zdg.md/en/?p=263\&fbclid=IwAR1Z7vqfqD6fNfl b1P9RkWBqmySbRn4COpWmme8EgNwUtzal7P7nuDfvwo0

Stratan, A., Chistruga, M., Clipa, V., Fala, A., \& Septelici, V. (2013). Development and side effects of remittances in the CIS countries: the case of Republic of Moldova. CARIM-East Research Report 2013/2. https://cadmus.eui.eu//handle/1814/27882

Stratan, A., \& Chistruga, M. (2012). Economic Consequences of Remittances. Case of Moldova. Procedia Economics and Finance, 3. https://doi.org/10.1016/s2212-5671(12)00295-x

Valetka, U. (2013). Development and Side Effects of Remittances in the CIS Countries: The Case of Belarus. SSRN Electronic Journal. Published. https://doi.org/10.2139/ssrn.2430806

World Bank, (2019). Personal remittances, received (\% of GDP) - Europe \& Central Asia (excl. high income) [Dataset]. https://data.worldbank.org/ indicator/BX.TRF.PWKR.DT.GD.ZS?loations=7E

World Bank (2021, May 12). Defying Predictions, Remittance Flows Remain Strong During COVID-19 Crisis [Press release]. https://www.worldbank.org/en/news/press-release/2021/05/12/ defyingpredictions-remittance-flows-remain-strong-during-covid-19-crisis 